\title{
Efektivitas Investasi Publik di Era Otonomi Daerah: Studi Kasus Pembangunan PASTY
}

\author{
Trisno Sakti Herwanto ${ }^{a} *$ \\ ${ }^{a}$ Universitas Katolik Parahyangan, Bandung, Jawa Barat, Indonesia
}

INFORMASI ARTIKEL

\section{Article history:}

Dikirim tanggal: 22 Januari 2016

Revisi pertama tanggal: 09 Februari 2016

Diterima tanggal: 3 Mei 2016

Tersedia online tanggal: 11 Juni 2015

Keywords: public investment effectiveness, cost and benefit analysis

\section{ABSTRACT}

This paper aims to examine the effectiveness of public investment on the public investment of Yogyakarta Animal and Plant Market (PASTY) development. Cost and Benefit Analysis was applied to measure the PASTY values. We found that the investment of PASTY development gives effective impact on welfare with a positive NPV value IDR 26 billion. Factors that affect the effectiveness of the development of PASTY are sound policy formulation process, collaborative action in the policy implementation process, clear fragmentation of work and responsibility of government agencies, and availability of resources.

\section{INTISARI}

Tulisan ini bertujuan memahami efektivitas investasi publik pada pembangunan Pasar Satwa dan Tanaman hias Yogyakarta (PASTY). Analisis Biaya-Manfaat dipilih sebagai metode yang digunakan dalam penelitian ini karena mampu menghadirkan kerangka analisis variabel biaya dan manfaat secara komprehensif.. Berdasarkan penelitian yang telah dilakukan, investasi pembangunan PASTY terbukti efektif memberikan dampak kesejahteraan dengan nilai NPV positif sebesar 26 Milyar rupiah. Terdapat beberapa faktor yang mempengaruhi efektivitas kebijakan pembangunan PASTY yaitu dominasi elit pada proses formulasi kebijakan, kolaborasi berbagai pihak pada proses implementasi kebijakan, pembagian tugas dan tanggung jawab yang jelas pada organisasi pemerintah serta ketersediaan sumberdaya.

2016 FIA UB. All rights reserved.

\section{Pendahuluan}

Karya tulis ini disusun berdasarkan hasil penelitian dengan judul "Analisis Investasi Publik di Era Otonomi Daerah: Pembangunan Pasar Satwa dan Tanaman Hias Yogyakarta (PASTY)" yang dibiayai oleh program beasiswa ISB (In Search of Balance) kerjasama Universitas Gadjah Mada dan Universitetet i Agder Norwegia Batch 3 Tahun 2015. Secara khusus tulisan in diarahkan untuk menjelaskan efektivitas dampak kesejahteraan investasi yang dilakukan Pemerintah Kota
Yogyakarta dengan menginisiasi kebijakan pembangunan Pasar Satwa dan Tanaman Hias Yogyakarta. Untuk memperoleh pemahaman secara lebih mendalam dan komprehensif, dilakukan langkah eksplorasi faktor-faktor yang mempengaruhi efektivitas kebijakan pembangunan Pasar Satwa dan Tanaman Hias Yogyakarta.

Investasi merupakan sebuah konsep yang tidak hanya menjadi fokus kajian sektor swasta namun telah menjadi kajian penting di sektor publik. Berbeda dengan

* Corresponding author. Tel.: +62-22-2033557; fax: +62-22-2035755; e-mail: trisnosakti@ unpar.ac.id 
investasi sektor swasta yang cenderung diarahkan untuk mencapai manfaat perusahaan berupa uang, investasi publik secara spesifik dilakukan pemerintah untuk menciptakan kesejahteraan masyarakat. Pemikiran tersebut terkonfirmasi melalui pendapat Samuelson dan Nordhaus (2001) yang menyatakan bahwa pemerintah merupakan lembaga yang memiliki peran pokok mendorong pencapaian kesejahteraan masyarakat melalui kebijakan investasi.

Berdasarkan orientasi pada kesejahteraan masyarakat, investasi di sektor publik dapat dipahami sebagai sebuah upaya yang lebih kompleks dibandingkan investasi di sektor swasta. Ketika perusahaan swasta cenderung hanya terfokus pada upaya memperoleh manfaat berupa uang, pemerintah justru memiliki tanggung jawab yang besar untuk dapat menciptakan kesejahteraan masyarakat melalui kebijakan investasi.

Kompleksitas kebijakan investasi yang dihadapi pemerintah tersebut seharusnya dapat berkurang seiring desentralisasi pemerintahan dan otonomi daerah. Otonomi daerah membawa harapan baru bagi pencapaian kesejahteraan masyarakat karena dengan semangat demokrasi, terdapat partisipasi aktif daerah dan berbagai aktor dalam mengelola berbagai permasalahan publik. Pemahaman ini dipertegas oleh Kim (2011) yang menjelaskan bahwa melalui partisipasi dan kolaborasi berbagai pihak di daerah, diharapkan terwujud tata kelola pemerintahan daerah yang baik sehingga tercipta kesejahteraan masyarakat secara efektif dan efisien.

Otonomi daerah dan semangat untuk menyejahterakan masyarakat telah mendorong berbagai daerah menginisiasi kebijakan investasi. Langkah investasi daerah ini dilandasi oleh PP Nomor 1 Tahun 2008 tentang Investasi Pemerintah dan secara lebih jelas diatur dalam Permendagri Nomor 52 Tahun 2012 tentang Pedoman Pengelolaan Investasi Pemerintah Daerah. Pada kedua peraturan tersebut dinyatakan dengan jelas bahwa kebijakan investasi merupakan kebijakan yang dikelola dan menjadi tanggung jawab pemerintah daerah dalam rangka mencapai kesejahteraan rakyat.

Secara jelas, kebijakan investasi dalam rangka menyejahterakan masyarakat telah diinisiasi oleh Pemerintah Kota (Pemkot) Yogyakarta. Melalui alokasi berbagai sumberdaya yang dimiliki, Pemkot Yogyakarta berhasil mendirikan Pasar Satwa dan Tanaman Hias Yogyakarta (PASTY) di wilayah Dongkelan pada 22 April 2010. Pembangunan PASTY sebenarnya merupakan implikasi dari kebijakan yang diambil Pemerintah Daerah (Pemda) DIY. Pemda DIY berencana merevitalisasi lingkungan Kraton sebagai cagar budaya dan pusat pariwisata Yogyakarta. Keberadaan pasar satwa yang kotor, bau dan tidak tertata rapi di Pasar Ngasem dipandang pemerintah kurang mendukung upaya revitalisasi Kraton sehingga pedagang satwa perlu dipindahkan. Dongkelan kemudian dipilih sebagai lokasi baru bagi pedagang satwa karena sebelumnya telah terdapat pedagang tanaman hias yang beroperasi di wilayah tersebut. Pemkot Yogyakarta berpandangan bahwa karakteristik barang dagangan yang hampir sama memungkinkan pedagang satwa dan tanaman hias hidup secara berdampingan.

Meskipun hanya merupakan implikasi dari kebijakan lain, Pemkot Yogyakarta berusaha mewujudkan lingkungan pasar baru yang lebih baik. PASTY dibangun di lahan yang lebih luas dibandingkan Pasar Ngasem. Lingkungan PASTY juga lebih bersih dan tertata rapi. Selain luas, bersih dan tertata rapi, PASTY juga dilengkapi dengan berbagai fasilitas penunjang seperti tempat ibadah, toilet, area parkir kendaraan yang luas, instalasi air siap minum dan area bermain anak. Lingkungan pasar yang lebih baik tersebut diharapkan mampu meningkatkan daya tarik konsumen sehingga tercipta peningkatan kesejahteraan ekonomi pedagang satwa dan pedagang tanaman hias. Kehidupan ekonomi pasar yang terus berkembang diharapkan dapat memunculkan keterlibatan wirausahawan baru dan memberikan dampak kesejahteraan masyarakat Dongkelan secara lebih luas. Selain ditujukan untuk meningkatkan kesejahteraan ekonomi, lingkungan pasar yang lebih baik juga diharapkan mampu memberikan kenyamanan bagi para pedagang satwa untuk menjalankan aktivitas di pasar.

Berdasarkan tujuan kebijakan berupa kesejahteraan masyarakat, diperlukan langkah evaluasi komprehensif yang diarahkan untuk menjelaskan efektivitas dampak kesejahteraan investasi pembangunan PASTY. Evaluasi efektivitas investasi publik secara komprehensif dilakukan dengan membandingkan seluruh biaya yang dikeluarkan dan manfaat yang diperoleh para aktor. Sesuai pemahaman mengenai investasi publik, biaya dan manfaat yang diamati dalam karya tulis ini tidak hanya terfokus pada biaya dan manfaat finansial berdasarkan mekanisme pasar namun juga pada jenis biaya dan manfaat sosial. Selain terfokus untuk menjelaskan efektivitas dampak kesejahteraan investasi, dilakukan eksplorasi mengenai faktor-faktor yang mempengaruhi efektivitas kebijakan pembangunan PASTY. Langkah tersebut dilakukan untuk memberikan pemahaman secara lebih mendalam dan komprehensif mengenai efektivitas investasi pembangunan PASTY.

Investasi pembangunan PASTY menjadi penting untuk diteliti karena kebijakan tersebut berada dalam konteks lokal yang unik. Pembangunan PASTY diinisiasi Pemkot Yogyakarta sebagai implikasi dari kebijakan revitalisasi Kraton Yogyakarta yang diambil oleh Pemda DIY. Dalam kasus ini, kebijakan berada 
dalam konteks kepemimpinan lokal Sri Sultan HB X yang sangat berbeda dengan karakteristik kepemimpinan daerah lain. Sri Sultan HB X adalah Raja Kraton Yogyakarta sekaligus Gubernur DIY yang ditetapkan tanpa melalui mekanisme pemilihan langsung oleh rakyat. Konteks kebijakan tersebut diharapkan dapat memunculkan hasil analisis yang kontributif, terutama bagi kajian kebijakan publik yang dikelola oleh pemerintah lokal di era otonomi daerah.

\section{Teori}

\section{Investasi publik}

Secara sederhana, Halim (2008) mendefinisikan investasi sebagai aktivitas belanja modal (capital expenditure) berupa pembiayaan atau pengeluaran yang memberi manfaat lebih dari satu tahun. Secara lebih komprehensif, investasi dijelaskan Jones (2004) sebagai komitmen pendanaan untuk melakukan pengadaan aset dalam rangka mencapai hasil tertentu yang diinginkan. Dalam pendekatan sektor swasta, investasi dijelaskan Jones sebagai aktivitas yang diarahkan untuk mendapatkan uang atau kesejahteraan moneter investor. Investor melakukan investasi dengan mengeluarkan biaya berupa uang untuk mendapatkan manfaat berupa uang yang lebih besar.

Berbeda dengan pemahaman investasi yang digunakan swasta, investasi sektor publik dipahami sebagai sebuah aktivitas yang dilakukan untuk meraih manfaat kesejahteraan masyarakat. Investasi publik dijelaskan Anderson, de Renzio dan Levy (2006) sebagai kegiatan belanja publik (public expenditure) yang dilakukan oleh pemerintah bukan untuk meraih manfaat langsung bagi dirinya melainkan meraih manfaat yang luas bagi masyarakat. Turini (2004) menegaskan investasi publik penting untuk dilakukan oleh pemerintah karena terjadi fenomena kegagalan pasar. Mekanisme pasar telah gagal menyediakan barang dan jasa yang dibutuhkan masyarakat sehingga dibutuhkan campur tangan negara dengan melakukan kebijakan investasi.

\section{Efektivitas kebijakan investasi publik}

Sesuai pendapat Purwanto dan Sulistyastuti (2012), efektivitas kebijakan publik dapat diketahui dari sejauh mana tujuan atau hasil yang diinginkan dari kebijakan dapat dicapai. Pengukuran efektivitas kinerja kebijakan tidak hanya terbatas pada keluaran kebijakan atau policy output melainkan lebih terfokus pada hasil kebijakan atau policy outcome. Sebuah kebijakan dapat dikatakan efektif apabila tercipta dampak perubahan kondisi kelompok sasaran ke arah yang lebih baik sesuai tujuan kebijakan. Penjelasan tersebut dipertegas oleh Baker dan Sabo (2004) yang menyatakan bahwa efektivitas sebuah kebijakan ditentukan oleh logika kebijakan yang mencakup dua pokok perhatian yaitu tujuan dan hasil atau dampak kebijakan.

Berdasarkan logika tersebut, sebagai sebuah kebijakan, investasi publik dapat dikatakan efektif apabila tujuan atau dampak yang diharapkan dapat diraih. Menurut Bobrow dan Dryzek (1987), investasi publik atau investasi yang dilakukan pemerintah memiliki tujuan meraih keuntungan atau manfaat berupa kesejahteraan masyarakat. Tujuan kebijakan investasi publik berupa kesejahteraan masyarakat berakar dari aliran ekonomi kesejahteraan (welfare economic) yang tidak hanya memiliki perhatian pada keuntungan finansial. Adelman dan Morris (1973) menjelaskan bahwa teori ekonomi telah mengalami pergeseran dari ekonomi murni ke ekonomi yang memperhatikan aspek keadilan sosial. Konsekuensi dari pergeseran ilmu ekonomi ini yaitu dampak yang luas bagi kelompokkelompok masyarakat harus turut mendapat perhatian.

Dalam melihat efektivitas dari sebuah kebijakan investasi, Jones (2004) menyarankan penggunaan analisis investasi yang dilakukan dengan membandingkan nilai biaya dan nilai manfaat dari kebijakan yang telah dilaksanakan. Apabila nilai manfaat yang diperoleh lebih besar dibandingkan nilai biaya, maka kebijakan investasi dapat dikatakan efektif. Berkaitan dengan investasi publik, variabel biaya dan manfaat yang diamati tidak hanya terbatas pada manfaat finansial namun juga memiliki perhatian pada kondisi sosial ekonomi masyarakat. Sesuai penjelasan Boulding (1958), dalam perspektif ekonomi kesejahteraan, fungsi kesejahteraan tidak terbatas pada pertumbuhan ekonomi yang dinilai oleh kaum ekonom melainkan kondisi sosial ekonomi yang dirasakan oleh kelompok masyarakat.

Penjelasan Boulding diperkuat oleh Bank Dunia (2001) yang menjelaskan bahwa pencapaian kesejahteraan tidak hanya berfokus pada pengentasan kemiskinan namun lebih terfokus pada pembangunan kualitas hidup masyarakat secara utuh. Pembangunan kualitas hidup masyarakat bukan hanya berkaitan dengan peningkatan pendapatan per kapita namun juga aspek lain seperti peningkatan rasa aman dan lingkungan yang lebih lestari. Secara spesifik Pearce, Atkinson, dan Mourato (2006) menjelaskan manfaat non-finansial sebagai increases in human well-being dan biaya non-finansial sebagai reductions in human well-being.

\section{Faktor-faktor yang mempengaruhi efektivitas kebijakan publik}

Efektivitas kebijakan publik tidak dapat terlepas dari proses atau tahapan kebijakan. Parsons (2008) menjelaskan bahwa siklus hidup kebijakan masih 
digunakan sebagai dasar dalam melakukan analisis kebijakan publik termasuk untuk mengamati efektivitas kebijakan. Pendapat Parsons tersebut dipertegas oleh Putra (2003) yang menjelaskan bahwa efektivitas kebijakan publik tidak dapat terlepas dari dua proses utama yaitu proses formulasi dan implementasi kebijakan. Formulasi kebijakan merupakan langkah paling awal dalam proses kebijakan publik sehingga apa yang terjadi dalam fase ini akan sangat menentukan keberhasilan kebijakan pada masa yang akan datang. Keberhasilan kebijakan juga sangat bergantung pada proses implementasi karena untuk mencapai tujuan kebijakan, pelaksanaan kebijakan harus terkait dengan tujuan yang telah ditetapkan.

Berdasarkan pemahaman tersebut, identifikasi faktor-faktor yang mempengaruhi efektivitas kebijakan publik dapat dijelaskan dengan mengamati faktor-faktor dalam proses formulasi dan implementasi kebijakan. Melalui pemahaman terhadap model-model formulasi dan implementasi kebijakan, faktor-faktor yang mempengaruhi keberhasilan kebijakan publik dapat dijelaskan sebagai berikut

\section{Faktor-faktor yang mempengaruhi proses formulasi}

Parsons (2008) menjelaskan bahwa kekuasaan merupakan variabel utama yang dapat mempengaruhi proses formulasi kebijakan. Konfigurasi kekuasaan yang terpusat pada golongan elit atau terdistribusi kepada aktor yang lebih luas sangat menentukan karakteristik produk kebijakan. Penjelasan Parsons tersebut di pertegas oleh Wibawa (2011) yang menjelaskan bahwa proses kebijakan publik seringkali dipengaruhi oleh kekuasaan atau faktor politik yang sangat besar.

Selain pengaruh konfigurasi kekuasaan, Winarno (2012) menjelaskan beberapa faktor yang dapat mempengaruhi formulasi kebijakan yaitu kemampuan pembuat kebijakan, keterbatasan sumberdaya, peran kelompok kepentingan dan struktur kelembagaan. Secara lebih komprehensif, Hill (2005) memaparkan berbagai faktor yang dapat mempengaruhi proses formulasi kebijakan yaitu konfigurasi kekuasaan, negosiasi antar lembaga pemerintah, pedoman nilai pembuat kebijakan, kapasitas SDM dalam melakukan problem-solving, keterbatasan informasi, keterbatasan biaya, keterbatasan metode evaluasi kebijakan sebelumnya dan konteks atau lingkungan kebijakan.

\section{Faktor-faktor yang mempengaruhi proses implementasi}

Sesuai pendapat Hill dan Hupe (2002), implementasi merupakan sebuah aktivitas yang kompleks. Pemikiran tersebut muncul karena pada tataran praktis ditemukan berbagai faktor yang berpengaruh terhadap keberhasilan implementasi kebijakan. Berdasarkan penjelasan Subarsono (2005), implementasi kebijakan sangat dipengaruhi oleh kejelasan standar dan sasaran kebijakan, ketersediaan sumberdaya meliputi SDM maupun sumberdaya lainnya, hubungan antar organisasi, karakteristik agen pelaksana serta kondisi sosial, ekonomi dan politik. Secara lebih sederhana beberapa variabel yang mempengaruhi implementasi kebijakan dijelaskan Edward III (1980) meliputi komunikasi, sumberdaya, disposisi atau watak implementor dan struktur birokrasi.

Model implementasi Grindle kemudian muncul dan menawarkan perhatian pada variabel konteks atau lingkungan kebijakan yang sebelumnya seringkali diabaikan. Grindle (dalam Nugroho, 2008; Subarsono, 2005) menjelaskan keberhasilan implementasi kebijakan ditentukan oleh dua variabel pokok yaitu isi kebijakan (content of policy) dan lingkungan implementasi (context of implementation). Variabel isi kebijakan mencakup kepentingan yang terpengaruhi oleh kebijakan, jenis manfaat yang akan dihasilkan, derajat perubahan yang diinginkan, kedudukan pembuat kebijakan, pelaksana program dan sumberdaya. Variabel konteks implementasi berkaitan dengan kekuasaan, kepentingan dan strategi aktor yang terlibat, karakteristik lembaga dan penguasa, serta kepatuhan dan daya tanggap kelompok sasaran.

Secara mendetail, Hogwood dan Gunn (dalam Purwanto dan Sulistyastuti, 2012) memaparkan beberapa hal yang dapat menyebabkan kegagalan implementasi kebijakan yaitu hambatan kondisi eksternal organisasi, waktu dan sumberdaya tidak memadai, kebijakan tidak didasarkan pada hubungan kausalitas yang kuat, dampak kebijakan bersifat tidak langsung, lembaga pelaksana tidak mandiri, kurangnya kesepakatan para aktor terkait tujuan dan cara mencapai tujuan serta terdapat permasalahan koordinasi dan komunikasi.

\section{Metode Penelitian}

Pendekatan campuran (mixed-method) digunakan dalam penelitian ini karena terdapat dua tujuan penelitian yaitu menjelaskan dan memahami efektivitas investasi pembangunan PASTY. Pendekatan penelitian campuran diaplikasikan dengan menggunakan CBA untuk menjelaskan efektivitas dampak kesejahteraan investasi pembangunan PASTY dan pendekatan kualitatif untuk memahami faktor-faktor yang mempengaruhi efektivitas kebijakan.

Sesuai pendapat Dunn (2000), CBA memiliki keunggulan dalam melakukan perbandingan biaya dan manfaat dari sebuah kebijakan karena seluruh biaya dan manfaat dari sebuah kebijakan dapat dikonversi ke dalam nilai mata uang. Pearce, Atkinson, dan Mourato (2006) menjelaskan bahwa CBA merupakan alat analisis yang obyektif dan akuntabel karena memandang 
preferensi publik sebagai dasar evaluasi kesejahteraan. Meskipun relevan dan memiliki keunggulan, Greenberg, Vining dan Weimer (1996) menjelaskan bahwa CBA memiliki kelemahan yaitu keterbatasan sumberdaya dan data yang ada seringkali menjadi hambatan untuk menilai seluruh biaya dan manfaat kebijakan.

Sesuai penjelasan Stiglitz (1988), biaya dan manfaat yang diamati dalam penelitian ini meliputi marketed and non-marketed commodities. Marketed commodities merupakan segala bentuk biaya dan manfaat yang memiliki nilai sesuai harga aktual pasar, sedangkan non-marketed commodities adalah segala bentuk biaya dan manfaat dengan nilai yang tidak mengikuti harga aktual pasar. Secara sistematis proses analisis dengan menggunakan CBA dalam penelitian ini dapat dijelaskan sebagai berikut

\section{Identifikasi aktor}

Pada tahap ini dilakukan identifikasi aktor baik pemerintah maupun komunitas masyarakat yang mengeluarkan biaya dan memperoleh manfaat dari pembangunan PASTY.

\section{Identifikasi biaya dan manfaat}

Setelah dilakukan indentifikasi aktor, dilakukan identifikasi seluruh biaya yang dikeluarkan dan manfaat yang diperoleh oleh aktor-aktor tersebut.

\section{Konversi biaya dan manfaat ke dalam nilai rupiah}

Seluruh biaya dan manfaat yang telah diidentifikasi dikonversi ke dalam nilai mata uang rupiah. Biaya dan manfaat yang tidak dihitung oleh para aktor dikonversi ke dalam nilai mata uang rupiah dengan konsep harga bayangan (shadow price). Penyesuaian dengan harga aktual pasar dan pembobotan oleh aktor dilakukan untuk dapat mengkonversi seluruh biaya dan manfaat. Pembobotan nilai oleh aktor dilakukan dengan metode Contingent Valuation (CV) yaitu survei untuk mencari nilai maksimal Willingness to Pay (WTP max) manfaat dan nilai minimal Willingness to Accept (WTA min) biaya yang mereka rasakan. Metode penarikan sampel yang digunakan dalam $\mathrm{CV}$ adalah simple random sampling dan sesuai pendapat Gay dan Diehl (dalam Mustafa, 2003), untuk penelitian deskriptif, jumlah sampel minimal yang digunakan sebesar $10 \%$ dari jumlah populasi.

\section{Penghitungan Net Present Value (NPV)}

Setelah dikonversi ke dalam nilai rupiah, dilakukan penyajian data biaya dan manfaat per tahun selama proyek berjalan. Dilakukan perhitungan nilai bersih masa sekarang atau Net Present Value (NPV) dengan discount factor berdasarkan tingkat bunga sebesar $12 \%$ untuk kebijakan publik. Berdasarkan observasi dan wawancara yang dilakukan, ditetapkan umur ekonomis pembangunan PASTY sebesar 25 tahun sejak tahun 2010. Investasi dapat dikatakan efektif apabila NPV bernilai positif (+) dan belum efektif apabila NPV bernilai negatif (-).

\section{Hasil Penelitian dan Pembahasan}

\section{Aktor, biaya dan manfaat pembangunan PASTY}

Aktor serta berbagai bentuk biaya dan manfaat dari investasi pembangunan PASTY dapat dijelaskan sebagai berikut:

\section{Pemerintah}

Pemerintah merupakan aktor yang mengeluarkan biaya berupa biaya investasi dan biaya operasional PASTY. Biaya investasi pembangunan PASTY dikeluarkan oleh Dinas Bangunan Gedung dan Aset Daerah (DBGAD) dan biaya operasional pasar dikeluarkan oleh Dinas Pengelolaan Pasar (Dinlopas) Kota Yogyakarta. Biaya investasi dan biaya opersional yang dikeluarkan pemerintah bersumber dari APBD Kota Yogyakarta tahun 2009-2014. Dalam penjabaran APBD, segala bentuk pembiayaan yang dikeluarkan Pemkot Yogyakarta terbagi menjadi tiga jenis pembelanjaan yaitu belanja pegawai, belanja barang dan jasa serta belanja modal.

Biaya investasi dikeluarkan DBGAD untuk membangun komponen fisik pasar hingga PASTY siap beroperasi. Pembangunan komponen fisik pasar terdiri dari pembangunan kios dan los, Kantor UPT PASTY, instalasi listrik, instalasi air bersih, pagar pembatas, saluran pembuangan air, toilet, taman, kubah burung dan fasilitas penunjang lainnya. Pemerintah sebenarnya juga mengeluarkan biaya investasi berupa biaya penggunaan lahan meskipun lahan di Dongkelan merupakan lahan milik Pemkot Yogyakarta. Untuk menilai penggunaan lahan tersebut, digunakan konsep harga bayangan berdasarkan nilai sewa lahan di sekitar pasar.

Setelah komponen fisik pasar selesai dibangun, pengelolaan PASTY diserahkan kepada Dinlopas Kota Yogyakarta. Sejak saat itu, Dinlopas mengeluarkan biaya operasional atau yang dijelaskan dalam realisasi belanja anggaran Dinlopas sebagai Optimalisasi Pengelolaan PASTY. Belanja pegawai serta belanja barang dan jasa rutin dilakukan setiap tahun, sedangkan belanja modal dilakukan Dinlopas apabila terdapat kebutuhan mesin atau alat penunjang operasional pasar.

Melalui pembiayaan tersebut, pemerintah memperoleh manfaat berupa penerimaan retribusi dari berbagai aktivitas PASTY. Penerimaan retribusi dari 
aktivitas PASTY terdiri dari penerimaan retribusi kios, los dan lapak, retribusi toilet, retribusi listrik, retribusi jasa parkir dan retribusi pemanfaatan atau sewa lahan. Retribusi pemanfaatan lahan merupakan pendapatan dari pihak swasta yang melakukan langkah promosi atau mengadakan kegiatan yang bersifat komersial di lingkungan PASTY.

\section{Komunitas pedagang}

Komunitas pedagang yang mengeluarkan biaya dan memperoleh manfaat dari pembangunan PASTY terdiri dari kelompok pedagang satwa, pedagang tanaman hias dan pedagang makanan. Pada awal operasional PASTY, muncul komunitas pedagang makanan yang sebelumnya berprofesi sebagai ibu rumah tangga. Pedagang makanan tersebut merupakan istri atau kerabat dari pedagang satwa. Mereka dapat berdagang dan memperoleh hak kios atau los pasar karena memperoleh informasi pendaftaran anggota pedagang pasar dari paguyuban pedagang satwa.

Dalam menjalani aktivitas berdagang di PASTY, komunitas pedagang mengeluarkan biaya dalam bentuk biaya produksi dan biaya modal. Biaya produksi merupakan biaya yang dikeluarkan pedagang untuk memproduksi barang sebagai produk dari unit usahanya. Biaya modal merupakan biaya yang dikeluarkan pedagang untuk mendukung operasionalisasi unit usaha seperti pembelian etalase, kandang hewan, rak tanaman, gerobak, peralatan masak, dan lain sebagainya. Kelompok pedagang sebenarnya mengeluarkan biaya tenaga kerja namun biaya ini tidak dihitung karena mereka cenderung menjalankan sendiri unit usahanya. Untuk menilai biaya tenaga kerja, digunakan konsep harga bayangan berdasarkan nilai tenaga kerja masingmasing kelompok pedagang.

Selain biaya produksi, biaya modal dan biaya tenaga kerja, terdapat biaya yang tidak mengikuti harga pasar. Pedagang satwa mengeluarkan biaya berupa rasa aman yang hilang semenjak berdagang di PASTY. Pada tahun 2010 dan 2011, pedagang merasa khawatir terhadap keamanan barang dagangan yang diletakkan di PASTY. Meskipun penjagaan petugas keamanan pasar dilakukan selama 24 jam, para pedagang tidak dapat mengakses kios/los secara bebas setelah jam operasional pasar berakhir. Kondisi ini sangat berbeda dengan yang mereka rasakan di Pasar Ngasem. Ketika berdagang di Pasar Ngasem, para pedagang bebas mengakses atau bahkan menginap di kios atau los yang mereka miliki. Rasa aman yang hilang semakin besar ketika terjadi serangkaian peristiwa pencurian satwa di PASTY mulai tahun 2012 hingga 2014.

Komunitas pedagang PASTY memperoleh manfaat berupa pendapatan dari hasil operasional unit usahanya. Selain manfaat berupa pendapatan dari operasional unit usahanya, terdapat manfaat yang tidak mengikuti harga pasar. Pedagang satwa memperoleh manfaat berupa kenyamanan lingkungan fisik pasar yang sebelumnya tidak mereka rasakan di Pasar Ngasem. Berbeda dengan lingkungan Pasar Ngasem yang sempit dan terkesan kumuh, lingkungan PASTY yang luas, bersih dan tertata rapi menimbulkan kenyamanan bagi pedagang satwa dalam menjalankan aktivitas di pasar.

\section{Masyarakat sekitar pasar}

Biaya dan manfaat dari pembangunan PASTY tidak hanya dirasakan oleh pemerintah dan komunitas pedagang namun juga dirasakan oleh masyarakat Dongkelan. Biaya dan manfaat dirasakan oleh masyarakat Dongkelan yang tergabung dalam paguyuban pengelola parkir PASTY. Ketika PASTY mulai beroperasi, masyarakat sekitar pasar membentuk sebuah paguyuban untuk mengelola jasa parkir kendaraan pengunjung. Sebagian besar pengelola parkir PASTY sebelumnya bekerja sebagai buruh bangunan.

Paguyuban pengelola parkir mengeluarkan biaya berupa biaya modal. Biaya modal hanya dikeluarkan oleh pengelola parkir pada awal operasional PASTY untuk pembelian seragam serta perlengkapan kerja. Sama seperti komunitas pedagang, pengelola parkir tidak menghitung biaya tenaga kerja karena mereka mengelola parkir PASTY secara mandiri dengan sistem bagi hasil. Untuk menilai biaya tenaga kerja pengelola parkir, digunakan konsep harga bayangan berdasarkan nilai tenaga kerja buruh bangunan sesuai harga aktual pasar.

\section{Efektivitas pembangunan PASTY}

Investasi pembangunan PASTY hingga umur ekonomis tahun kelima (2010-2014) terbukti efektif memberikan dampak kesejahteraan. Efektivitas dampak kesejahteraan investasi dapat dijelaskan dari hasil perhitungan NPV yang menunjukkan nilai positif sebesar Rp 25.946.473.622,00. Meskipun terbukti efektif, dampak kesejahteraan investasi pembangunan PASTY mengalami tren yang semakin menurun.

Penurunan dampak kesejahteraan dapat diketahui dari tren nilai NPV per tahun yang semakin menurun seperti terlihat pada Grafik 1. Secara lebih jelas, penurunan dampak kesejahteraan dapat diketahui dari nilai Present Value Benefit (PVB) dan Present Value Cost (PVC) per tahun yang semakin berhimpit. Tren PVB dan PVC yang semakin berhimpit tersebut tentu harus menjadi perhatian pemerintah dalam melakukan berbagai program aksi pengelolaan pasar pada masa yang akan datang. Apabila nilai PVC berhasil melampaui PVB maka dapat dipastikan bahwa pembangunan PASTY tidak akan membawa 
kesejahteraan namun justru dapat memberikan dampak kerugian pada umur ekonomis tersisa.

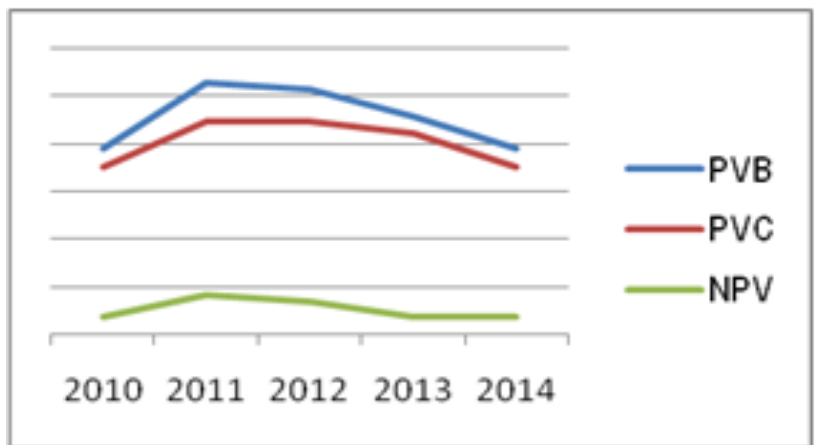

Grafik 1 PVB, PVC dan NPV Per Tahun (Sumber: Analisis Peneliti)

Fenomena penurunan dampak kesejahteraan dari investasi pembangunan PASTY dapat dipahami dengan melihat komposisi kesejahteraan seperti yang dijelaskan pada Grafik 2. Berdasarkan penjelasan Grafik 2, pedagang satwa merupakan kelompok yang memperoleh kesejahteraan paling besar dibandingkan aktor lainnya. Dapat dipahami bahwa penurunan kesejahteraan dirasakan pedagang satwa kemudian berimplikasi pada penurunan total dampak kesejahteraan pembangunan PASTY.

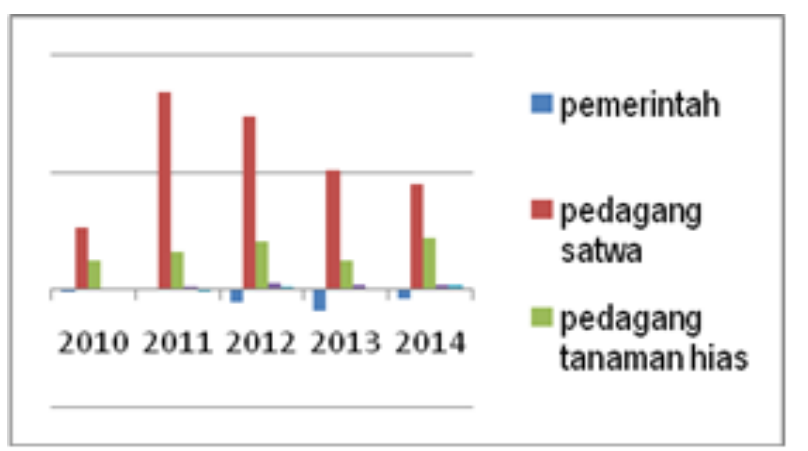

Grafik 2. Komposisi kesejahteraan pembangunan PASTY (Sumber: Analisis Peneliti)

Berdasarkan penjelasan Grafik 2, dapat diketahui bahwa terdapat perbedaan dampak kesejahteraan yang dialami oleh masing-masing aktor. Dampak kesejahteraan pembangunan PASTY dirasakan oleh pedagang satwa, pedagang tanaman hias, pedagang makanan dan pengelola parkir, sedangkan dampak kerugian justru dialami oleh pemerintah. Secara jelas, dampak kerugian dialami pemerintah pada tahun 2012, 2013 dan 2014 karena biaya yang dikeluarkan jauh lebih tinggi dibandingkan manfaat yang diperoleh.

Dampak kerugian yang dialami pemerintah dan kesejahteraan yang dialami pedagang satwa, pedagang tanaman hias, pedagang makanan dan pengelola parkir merupakan bukti bahwa investasi yang dilakukan pemerintah berhasil membawa dampak kesejahteraan bagi masyarakat sebagai kelompok sasaran kebijakan. Hasil analisis ini mengkonfirmasi pemahaman mengenai investasi publik yaitu investasi yang dilakukan pemerintah bukan untuk mendapatkan manfaat atau keuntungan finansial bagi dirinya sendiri, melainkan manfaat kesejahteraan bagi masyarakat. Upaya investasi publik dapat terus dilakukan demi manfaat yang besar dan luas bagi masyarakat meskipun pemerintah harus terus mengalami kerugian.

Secara lebih komprehensif, kesejahteraan yang tercipta dari investasi pembangunan PASTY dapat dipahami melalui penjelasan mengenai biaya dan manfaat yang dirasakan oleh masing-masing aktor sebagai berikut:

\section{Biaya dan manfaat yang dirasakan pemerintah}

Seperti yang telah dijelaskan pada bagian sebelumnya, komponen biaya yang dikeluarkan oleh pemerintah terdiri dari biaya investasi dan biaya operasional. Biaya investasi berupa biaya pembangunan fisik dan sewa lahan, dikeluarkan pemerintah setiap tahun dengan nilai konstan karena telah dibagi dengan umur ekonomis proyek yaitu 25 tahun. Berbeda dengan biaya investasi, nilai biaya operasional pembangunan PASTY mengalami fluktuasi setiap tahun. Fluktuasi biaya operasional tersebut kemudian berimplikasi pada fluktuasi total biaya yang dikeluarkan oleh pemerintah.

Biaya yang dikeluarkan pemerintah pada tahun 2010 dan 2011 masih cenderung rendah karena masih terdiri dari belanja rutin berupa belanja pegawai serta belanja barang dan jasa. Biaya yang dikeluarkan pemerintah mengalami peningkatan pada tahun 2012 karena terdapat biaya operasional berupa belanja pemeliharaan bangunan dan pengadaan berbagai peralatan UPT PASTY seperti peralatan elektronik dan peralatan rumah tangga. Biaya yang dikeluarkan pemerintah mencapai nilai tertinggi pada tahun 2013 karena terdapat aktivitas belanja perluasan bangunan kantor, belanja pengadaan perlengkapan kantor dan belanja perawatan kendaraan kantor. Nilai biaya yang dikeluarkan pemerintah mengalami penurunan pada tahun 2014 karena selain belanja pegawai serta belanja barang dan jasa, hanya dilakukan aktivitas belanja pemeliharaan perlengkapan Kantor UPT PASTY.

Grafik 3 Biaya dan manfaat pemerintah (Sumber:

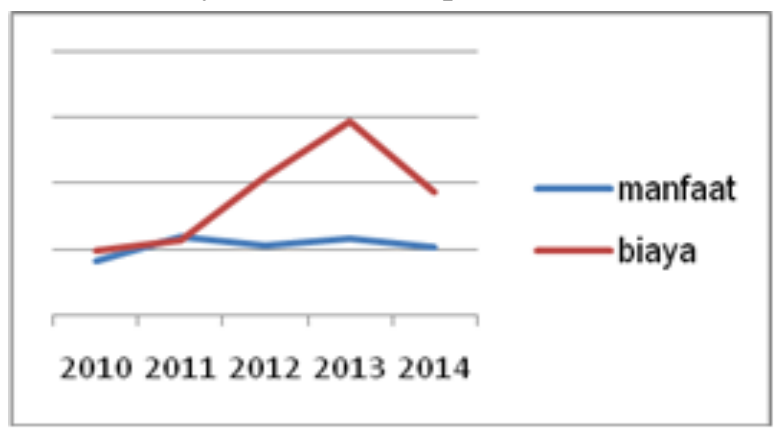

Analisis Peneliti) 
Melalui penjelasan mengenai komponen biaya yang dikeluarkan pemerintah, dapat dipahami bahwa aktivitas belanja modal masih cenderung dilakukan untuk memenuhi keperluan kantor dibandingkan untuk mengembangkan kehidupan sosial ekonomi pasar. Aktivitas belanja modal yang dilakukan oleh pemerintah untuk pengembangan kehidupan sosial ekonomi pasar masih terbatas pada kegiatan perawatan kebersihan dan keamanan pasar.

Berbeda dengan nilai biaya yang cenderung tinggi dan fluktuatif, manfaat yang diperoleh pemerintah cenderung rendah dan stabil. Seperti yang telah dijelaskan pada bagian sebelumnya, pemerintah memperoleh manfaat langsung berupa pendapatan retribusi dari aktivitas PASTY. Sesuai penjelasan Grafik 3, dapat diketahui bahwa manfaat yang diperoleh pemerintah setiap tahun mengalami peningkatan dan penurunan dengan selisih yang tidak terlalu signifikan. Fenomena ini terjadi karena terdapat kelompok pedagang yang mengajukan penundaan pembayaran retribusi operasional kios. Peningkatan manfaat yang diperoleh pemerintah kemudian terjadi karena terdapat kelompok pedagang yang membayar penundaan pembayaran retribusi operasional kios pada tahun sebelumnya.

\section{Biaya dan manfaat yang dirasakan pedagang satwa}

Biaya yang dikeluarkan oleh pedagang satwa mengalami tren peningkatan dari tahun 2010 hingga tahun 2013 dan mengalami penurunan pada tahun 2014. Biaya pada tahun 2010 relatif rendah karena umur efektif operasional PASTY pada tahun tersebut masih sebesar 8 bulan. Biaya yang dikeluarkan pedagang satwa terus mengalami peningkatan hingga tahun 2013 karena terdapat peningkatan biaya operasional unit usaha seperti kenaikan harga jasa tenaga kerja, kenaikan harga pakan satwa dan jasa transportasi. Selain biaya operasional, rasa aman terhadap lingkungan pasar yang semakin hilang juga turut berkontribusi meningkatkan nilai biaya yang dikeluarkan pedagang satwa. Setelah mencapai nilai tertinggi pada 2013, biaya yang dikeluarkan pedagang satwa mengalami penurunan pada tahun 2014 karena terjadi penurunan jumlah pedagang dan pengurangan skala usaha akibat penurunan jumlah konsumen.

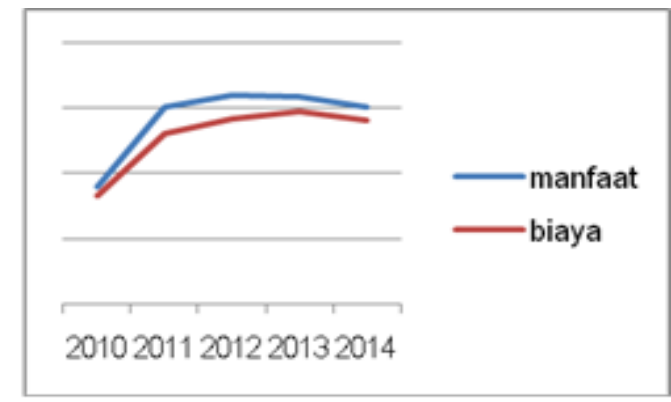

Grafik 4 Biaya dan manfaat pedagang satwa
Berdasarkan penjelasan pada Grafik 4, dapat diketahui bahwa nilai manfaat yang diperoleh pedagang satwa semakin berhimpit dengan nilai biaya. Fenomena ini menjelaskan bahwa kesejahteraan pedagang satwa semakin menurun. Meskipun manfaat berupa kenyamanan lingkungan PASTY semakin meningkat, manfaat berupa pendapatan dari operasional unit usaha semakin menurun. Pendapatan pedagang semakin menurun karena transaksi jual-beli yang tercipta di PASTY semakin menurun.

Berdasarkan hasil observasi dan wawancara, penurunan transaksi jual-beli bukan hanya disebabkan oleh penurunan jumlah konsumen, namun juga disebabkan oleh keberadaan pedagang liar yang beroperasi di sekitar PASTY. Tanpa harus membayar uang retribusi, para pedagang liar tersebut berdagang di sekitar pasar dan mengambil alih konsumen pedagang satwa.

Penurunan pendapatan yang dirasakan pedagang satwa mendorong mereka melakukan pengurangan skala usaha untuk dapat terus berdagang. Kondisi tersebut tidak didukung dengan keberadaan sumber pinjaman modal yang mudah diakses. Ketika pedagang satwa mencoba bertahan atau memperbesar skala usaha untuk mengimbangi keberadaan pedagang liar, mereka memilih melakukan pinjaman kepada pemburu rente meskipun tersedia mekanisme pinjaman modal dari kantor Bank BRI yang berada di lingkungan PASTY. Meskipun bunga pinjaman relatif tinggi yaitu sebesar 5$10 \%$, pedagang satwa memilih melakukan pinjaman modal kepada pemburu rente karena mereka dapat memperoleh uang sewaktu-waktu tanpa persyaratan khusus.

\section{Biaya dan manfaat yang dirasakan pedagang tanaman hias}

Biaya yang dikeluarkan oleh pedagang tanaman hias perlahan-lahan mengalami peningkatan hingga mencapai nilai tertinggi pada tahun 2013 dan kemudian mengalami penurunan pada tahun 2014. Seperti yang terjadi pada komunitas pedagang satwa, pada tahun 2010 biaya yang dikeluarkan oleh pedagang tanaman hias masih relatif rendah karena umur efektif operasional PASTY pada tahun tersebut masih sebesar 8 bulan. Biaya yang dikeluarkan pedagang tanaman hias terus mengalami peningkatan hingga tahun 2013 karena para pedagang mulai memperbesar skala usahanya. Semenjak PASTY didirikan, keberadaan pedagang satwa membawa dampak peningkatan pengunjung dan berimplikasi pada peningkatan transaksi jual-beli bagi pedagang tanaman hias. 


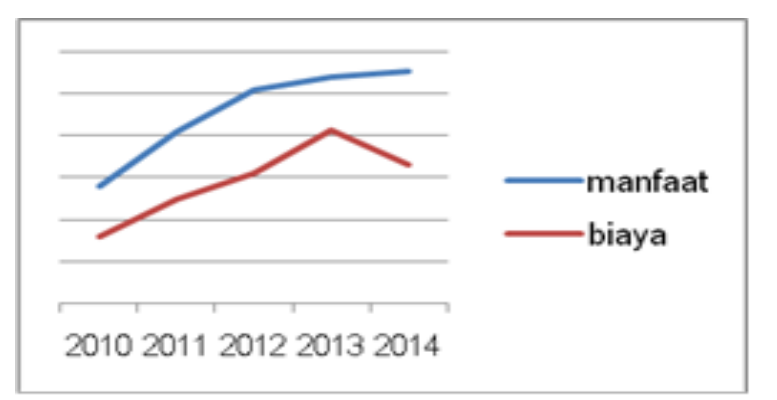

Grafik 5 Biaya dan manfaat pedagang tanaman hias (Sumber: Analisis Peneliti)

Akumulasi modal yang diperoleh pedagang tanaman hias kemudian mendorong mereka memperbesar skala usaha. Nilai biaya tertinggi dikeluarkan pedagang tanaman hias pada tahun 2013 karena dilakukan penambahan perlengkapan dagang dan penggantian perlengkapan-perlengkapan yang telah rusak seperti atap paranet dan atap plastik. Selain karena pengembangan skala usaha, peningkatan biaya yang dikeluarkan oleh pedagang tanaman hias juga terjadi karena terdapat kenaikan harga jasa tenaga kerja.

Berdasarkan penjelasan Grafik 5, dapat diketahui bahwa manfaat yang diperoleh pedagang tanaman hias semakin meningkat. Nilai manfaat yang semakin menjauh dari nilai biaya memberikan penjelasan bahwa dampak kesejahteraan yang dirasakan pedagang tanaman hias mengalami tren peningkatan. Peningkatan kesejahteraan tersebut terjadi karena semenjak pedagang satwa dipindahkan ke Dongkelan, para penggemar tanaman hias dari berbagai daerah di luar DIY mulai mengenal pasar tanaman hias PASTY. Para penggemar tanaman hias yang sebelumnya hanya berkunjung untuk berlibur, perlahan-lahan berubah menjadi konsumen dan pelanggan dari pasar tanaman hias PASTY.

\section{Biaya dan manfaat yang dirasakan pedagang makanan}

Biaya yang dikeluarkan oleh pedagang makanan mengalami tren peningkatan karena terjadi kenaikan harga kebutuhan pokok, jasa transportasi dan tenaga kerja. Nilai biaya mencapai nilai tertinggi pada Tahun 2013 karena para pedagang makanan memperbesar skala usahanya. Kondisi pasar satwa yang semakin ramai didatangi para pengunjung berimplikasi pada peningkatan konsumen pedagang makanan. Akumulasi modal yang diperoleh pedagang makanan mendorong mereka memperbesar skala usaha dengan memperbanyak jenis dagangan dan menambah perlengkapan dagang seperti etalase, kompor dan berbagai peralatan memasak.

Berdasarkan penjelasan Grafik 6, dapat diketahui bahwa manfaat yang diperoleh pedagang makanan semakin meningkat. Nilai manfaat yang semakin menjauh dari nilai biaya memberikan penjelasan bahwa dampak kesejahteraan yang dirasakan pedagang makanan mengalami tren peningkatan.

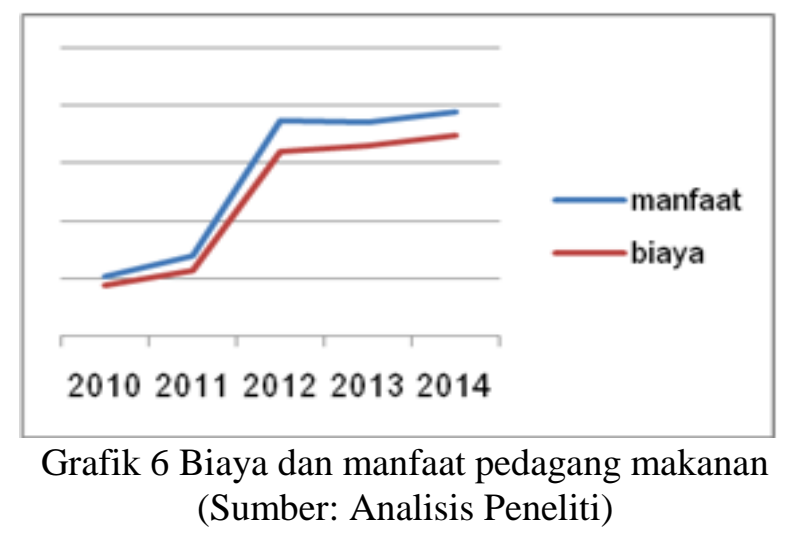

Biaya dan Manfaat yang Dirasakan Pengelola Parkir

Biaya yang dikeluarkan oleh pengelola parkir mengalami peningkatan secara signifikan pada tahun 2011 karena terjadi kenaikan harga tenaga kerja dan terus menurun hingga tahun 2014 karena penurunan jumlah tenaga kerja. Beberapa petugas parkir memutuskan untuk berhenti bekerja karena upah yang diperoleh berdasarkan sistem bagi hasil terlalu kecil.

Manfaat yang diperoleh pengelola parkir menunjukkan tren peningkatan karena pengunjung dan wisatawan yang datang ke PASTY semakin meningkat. Pada awal kemunculan PASTY, lingkungan pasar ramai pengunjung hanya pada akhir minggu atau hari libur lainnya. Perlahan-lahan, konsentrasi jumlah pengunjung mulai beralih ke hari-hari biasa seiring peningkatan jumlah pelanggan yang rutin berbelanja di PASTY.

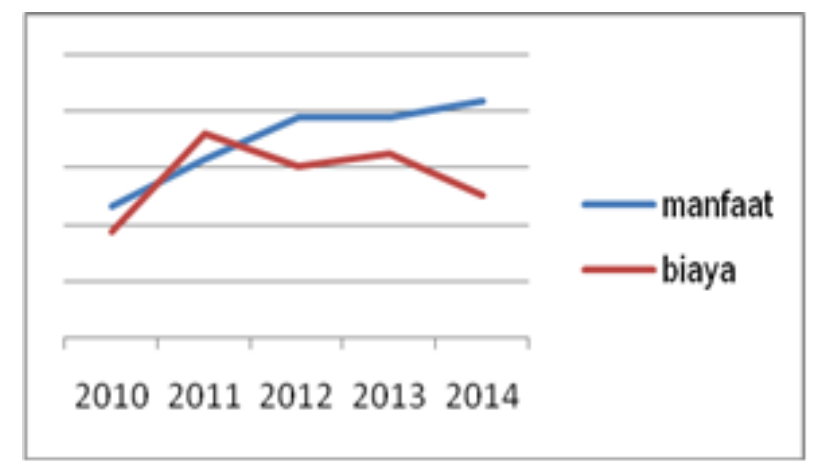

Grafik 7 Biaya dan manfaat pengelola parkir (Sumber: Analisis Peneliti)

Berdasarkan penjelasan Grafik 7, dapat dipahami bahwa dampak kesejahteraan yang dirasakan pengelola parkir semakin meningkat karena nilai biaya dan nilai manfaat semakin menjauh.

Melalui penjelasan biaya dan manfaat yang dirasakan oleh para aktor, dapat dipahami bahwa pemerintah mengalami kerugian, sedangkan pedagang satwa, pedagang tanaman hias, pedagang makanan dan pengelola parkir memperoleh dampak kesejahteraan dari pembangunan PASTY. Dampak kesejahteraan yang dirasakan pedagang satwa mengalami tren penurunan, 
sedangkan kesejahteraan pedagang tanaman hias, pedagang makanan dan pengelola parkir mengalami tren peningkatan. Temuan tersebut memberikan penjelasan bahwa kehadiran pedagang satwa di Dongkelan telah membawa dampak peningkatan kesejahteraan bagi pedagang tanaman hias, pedagang makanan dan pengelola parkir.

\section{Faktor-faktor yang mempengaruhi efektivitas pembangunan PASTY}

Berdasarkan hasil observasi dan wawancara yang dilakukan pada berbagai pihak, faktor-faktor yang mempengaruhi efektivitas kebijakan pembangunan PASTY dapat dijelaskan sebagai berikut:

\section{Dominasi elit pada proses formulasi kebijakan}

Efektivitas kebijakan pembangunan PASTY justru dihasilkan dari dominasi elit pada proses formulasi kebijakan. Dominasi elit yang terjadi pada kebijakan pembangunan PASTY berakar dari nilai budaya lokal masyarakat Yogyakarta yang masih menjadi pedoman pedagang satwa.

Kebijakan pembangunan PASTY merupakan kebijakan yang diambil Pemkot Yogyakarta sebagai implikasi dari kebijakan revitalisasi Kraton Yogyakarta yang diambil oleh Pemda DIY. Sri Sultan HB X, Gubernur DIY yang juga merupakan Raja Kraton Yogyakarta menghendaki pemindahan pedagang pasar satwa dari lingkungan Kraton Yogyakarta. Pemikiran Sri Sultan HB X tersebut muncul karena keberadaan pasar satwa yang kotor, bau dan kurang tertata dengan baik, tidak mendukung upaya revitalisasi Kraton Yogyakarta sebagai cagar budaya dan pusat pariwisata.

Secara sederhana, karakteristik kebijakan pembangunan PASTY sebagai implikasi dari kebijakan revitalisasi Kraton Yogyakarta dapat dipahami dengan mengamati hubungan antara masalah dan tujuan kebijakan yang tidak konsisten.

\begin{tabular}{|c|c|}
\hline $\begin{array}{c}\text { MASALAH } \\
\text { KEBIJAKAN } \\
\text { keberadaan pasar satwa } \\
\text { di kawasan Tamansari } \\
\text { dipandang tidak } \\
\text { mendukung revitalisasi } \\
\text { kawasan Kraton sebagai } \\
\text { cagar budaya dan pusat } \\
\text { pariwisata }\end{array}$ & $\begin{array}{c}\text { TUJUAN } \\
\text { KEBIJAKAN } \\
\text { peningkatan } \\
\text { kesejahteraan ekonomi } \\
\text { pedagang satwa dengan } \\
\text { pemberian lokasi pasar } \\
\text { yang lebih luas, bersih } \\
\text { dan tertata rapi }\end{array}$ \\
\hline
\end{tabular}

Gambar 1. Hubungan masalah dan tujuan kebijakan

(Sumber: Diolah dari Dinlopas Kota Yogyakarta)

Pembangunan PASTY yang diinisiasi untuk mencapai tujuan jangka pendek berupa peningkatan kesejahteraan ekonomi pedagang satwa tidak didasarkan pada masalah kesejahteraan ekonomi pedagang.
Kebijakan pembangunan PASTY justru diambil berdasarkan masalah kebijakan yaitu keberadaan pasar satwa di Tamansari tidak mendukung revitalisasi Kraton Yogyakarta sebagai cagar budaya dan pusat pariwisata.

Setelah Pemda DIY berkoordinasi dengan Pemkot Yogyakarta, ditetapkan sebuah keputusan bahwa untuk mendukung revitalisasi kawasan Kraton Yogyakarta, pedagang satwa akan dipindahkan ke lahan di Dongkelan. Keputusan tersebut dipandang pemerintah sebagai sebuah ide yang relevan karena terdapat kesamaan karakteristik barang dagangan antara pasar satwa dan pasar tanaman hias yang telah beroperasi di Dongkelan. Selain karena karakteristik barang dagangan, ide tersebut juga didukung oleh luas lahan di Dongkelan yang memadai untuk menampung ratusan pedagang satwa dari Pasar Ngasem.

Keputusan pemindahan pasar satwa yang telah disepakati oleh Pemda DIY dan Pemkot Yogyakarta tersebut kemudian disosialisasikan kepada seluruh pedagang satwa. Meskipun Pemkot Yogyakarta mengklaim bahwa telah dilakukan akomodasi terhadap aspirasi pedagang satwa, proses sosialisasi relokasi sangat diwarnai konteks nilai budaya lokal yang menghasilkan pengambilan keputusan tidak berjalan secara demokratis. Nilai budaya lokal yang masih menjadi karakteristik pedagang satwa justru dimanfaatkan oleh pemerintah untuk memperoleh kesepakatan mengenai keputusan relokasi.

Pemanfaatan nilai budaya lokal tampak pada proses sosialisasi relokasi berupa legitimasi pedagang satwa terhadap kepemimpinan Sri Sultan HB X sebagai seorang raja. Legitimasi kepemimpinan Sri Sultan HB X tersebut kemudian dimanfaatkan oleh pemerintah dengan melibatkan pihak Kraton Yogyakarta dalam proses sosialisasi relokasi. Selain melibatkan pihak Kraton, proses sosialisasi yang dilakukan di lingkungan Kraton Yogyakarta juga menjadi pendorong munculnya kata sepakat dari para pedagang satwa. Proses sosialisasi yang dilakukan untuk memperoleh kesepakatan dari pedagang satwa dilakukan di Sasana Hinggil, sebuah aula serba guna di lingkungan Kraton Yogyakarta.

Sosok Sri Sultan HB X dan Kraton Yogyakarta yang dimanfaatkan oleh pemerintah dalam proses sosialisasi terbukti menghasilkan kesepakatan relokasi dari para pedagang secara cepat dan tanpa diwarnai penolakan. Fenomena ini terjadi karena pedagang satwa memposisikan dirinya sebagai rakyat yang dipimpin oleh seorang raja. Segala keputusan yang diambil atau menjadi kehendak raja sudah seharusnya dipatuhi dan dijalankan oleh rakyatnya. Dalam kasus ini, pedagang satwa semakin patuh terhadap keputusan Sri Sultan HB $\mathrm{X}$ karena Pasar Ngasem merupakan pasar yang berdiri di wilayah Kraton Yogyakarta.

Berdasarkan analisis tersebut, dapat dipahami bahwa kaum elit yaitu pihak Kraton Yogyakarta menjadi 
aktor yang mendominasi proses formulasi kebijakan pembangunan PASTY. Elit kebijakan tersebut memiliki kekuasaan dan keleluasaan untuk memunculkan isu hingga melakukan langkah pengambilan keputusan. Pemanfaatan nilai budaya lokal yang dilakukan pemerintah justru menghasilkan mekanisme pengambilan keputusan yang tidak kolaboratif. Dominasi elit pada proses formulasi kebijakan tersebut kemudian menghasilkan kebijakan yang kurang akuntabel. Tujuan kebijakan yang diinisiasi oleh pemerintah tidak didasarkan pada masalah kebijakan yang sebenarnya terjadi dan dirasakan oleh pedagang satwa. Meskipun kebijakan bersifat kurang akuntabel, dominasi elit pada proses formulasi kebijakan mampu menghasilkan proses pengambilan keputusan yang cepat dan tanpa diwarnai konflik.

\section{Kolaborasi berbagai pihak pada proses implementasi kebijakan}

Selain karena dominasi elit pada proses formulasi kebijakan, efektivitas pembangunan PASTY dapat terwujud karena terdapat kolaborasi yang baik antara berbagai pihak pada proses implementasi kebijakan. Secara mendasar proses implementasi pembangunan PASTY terdiri dari dua proses pokok yaitu pembangunan fisik dan pembangunan kehidupan sosial ekonomi pasar. Berdasarkan langkah penelitian yang telah dilakukan, dapat disimpulkann bahwa pembangunan fisik dan pembangunan kehidupan sosial ekonomi pasar dilaksanakan secara kolaboratif antara pemerintah, swasta, akademisi dan masyarakat.

Meskipun pembangunan fisik pasar merupakan tanggung jawab Pemerintah Kota Yogyakarta, terdapat keterlibatan dari sektor swasta, akademisi dan masyarakat yaitu paguyuban pedagang satwa. Sebelum dilakukan perencanaan dan pelaksanaan pembangunan fisik PASTY, Pemkot Yogyakarta melalui Dinlopas melakukan pendataan kepada pedagang satwa sebagai dasar pemberian hak kios atau los. Melalui kerjasama dengan paguyuban pedagang satwa Pasar Ngasem, Dinlopas memperoleh data yang akurat terkait para pedagang satwa yang berhak mendapatkan kios atau los.

Selain kerjasama dalam proses pendataan pedagang, Dinlopas Kota Yogyakarta juga mengakomodasi aspirasi paguyuban pedagang satwa terkait tata letak kios dan los yang baru. Melalui komunikasi yang dibangun antara pemerintah dengan paguyuban pedagang satwa, diperoleh kesepakatan bahwa kios dan los di PASTY akan ditata berdasarkan jenis dagangan. Setelah terdapat kesepakatan terkait penataan kios dan los, dilakukan pembagian hak kios bagi para pedagang. Proses tersebut diserahkan sepenuhnya oleh Dinlopas kepada paguyuban pedagang satwa. Secara teknis, pembagian hak kios dan los bagi para pedagang dilakukan oleh setiap kelompok pedagang sesuai jenis dagangannya.

Kolaborasi berbagai pihak pada proses pembangunan kehidupan sosial ekonomi PASTY dapat dipahami ketika Dinlopas Kota Yogyakarta memfasilitasi terbentuknya Forum Silaturahmi Paguyuban Pedagang Pasar Yogyakarta (FSP3Y) pada tahun 2011. Forum tersebut menjadi wadah bagi paguyuban pedagang pasar seluruh Kota Yogyakarta untuk berpartisipasi aktif melakukan kegiatan pembangunan sosial ekonomi pasar ke arah yang lebih baik. Melalui forum tersebut tercipta langkah promosi berupa program belanja berhadiah. Pengelolaan program belanja berhadiah diserahkan sepenuhnya kepada paguyuban pedagang PASTY.

Dinlopas Kota Yogyakarta juga melibatkan masyarakat sekitar pasar untuk menciptakan dampak kesejahteraan yang luas dari pembangunan PASTY. Dinlopas Kota Yogyakarta meminta masyarakat sekitar untuk membentuk sebuah paguyuban sebagai sebuah organisasi yang bertanggungjawab mengelola jasa parkir PASTY. Melalui inisiasi yang dilakukan Dinlopas tersebut, terbentuk sebuah paguyuban pengelola parkir yang beranggotakan masyarakat Dongkelan. Secara kolaboratif jasa parkir PASTY dikelola oleh masyarakat dari dua kampung dan tiga Rukun Warga di Dongkelan.

Keterlibatan aktif sektor swasta untuk membangun kehidupan sosial ekonomi pasar juga terlihat dari berbagai kegiatan yang mereka lakukan di PASTY. Pihak swasta beberapa kali menginisiasi perlombaan satwa di PASTY seperti kontes ayam hias, kontes ikan hias dan kontes kicauan burung. Berbagai kegiatan perlombaan satwa tersebut berhasil meningkatkan jumlah kunjungan di lingkungan PASTY. Melalui berbagai kegiatan tersebut, muncul berbagai komunitas penggemar satwa yang kemudian menjadi konsumen dan pelanggan PASTY.

\section{Pembagian tugas dan tanggung jawab yang jelas}

Efektivitas pembangunan PASTY juga dihasilkan dari pembagian tugas dan tanggung jawab organisasi pemerintah yang jelas. Kejelasan pembagian tugas dan tanggung jawab terjadi baik antar organisasi maupun antar unit dalam organisasi pemerintah. Melalui pembagian tugas dan tanggung jawab yang jelas, berbagai isu dalam proses implementasi pembangunan PASTY dapat direspon dan dikelola dengan baik.

Pembagian tugas dan tanggung jawab yang jelas dapat diamati dari tugas yang diberikan kepada DBGAD dan Dinlopas Kota Yogyakarta. Secara jelas, DBGAD bertugas dan bertanggungjawab melakukan pembangunan komponen fisik sebelum pasar siap beroperasi. Setelah DBGAD menyelesaikan tugas pembangunan komponen fisik, tanggung jawab 
pembangunan kehidupan sosial ekonomi pasar diserahkan kepada Dinlopas.

Pembagian tugas dan tanggung jawab yang jelas juga dapat diamati dari struktur organisasi Dinlopas Kota Yogyakarta. Dalam struktur organisasi Dinlopas, terdapat tiga unit bidang dengan tanggungjawab dan tugas yang jelas. Bidang Pengembangan bertugas melakukan pengkajian, pengembangan dan pemasaran serta bertugas melakukan pembinaan pedagang dan komunitas pasar. Bidang Pemeliharaan Sarana Prasarana, Kebersihan dan Keamanan bertugas melakukan pemeliharaan sarana dan prasarana, pemeliharaan kebersihan dan pengamanan lingkungan pasar. Bidang Pemanfaatan Lahan dan Pengelolaan Retribusi bertugas mengelola penggunaan lahan pasar dan mengelola pendapatan retribusi dari aktivitas pasar. Selain terdapat tiga unit bidang dengan tugas dan tanggung jawab yang jelas, terdapat Unit Pelayan Teknis (UPT) yang dibentuk secara khusus untuk PASTY. Melalui keberadaan UPT PASTY yang terletak di lingkungan pasar, Dinlopas dapat melakukan berbagai aksi pengelolaan pasar seperti pengelolaan keamanan, ketertiban dan kebersihan, pemeliharaan sarana dan prasarana, penataan pedagang dan lahan, pemungutan dan pengelolaan retribusi, pembinaan dan pemberdayaan pedagang dan komunitas pasar, serta melaksanakan kegiatan promosi dan pemasaran.

\section{Ketersediaan sumberdaya}

Ketersediaan sumberdaya seringkali menjadi faktor utama yang menentukan efektivitas sebuah kebijakan. Berdasarkan langkah penelitian yang telah dilakukan, diperoleh informasi bahwa kebijakan pembangunan PASTY didukung oleh ketersediaan sumberdaya yang memadai. Dukungan sumberdaya pada kebijakan pembangunan PASTY tidak hanya berupa uang namun juga berupa lahan dan SDM.

Terkait sumberdaya dalam bentuk uang, dapat dipahami bahwa pemerintah memiliki dukungan sumberdaya yang lebih besar dibandingkan estimasi kebutuhan yang telah direncanakan. Realisasi belanja anggaran pemerintah selalu lebih kecil dibandingkan penganggaran yang telah ditetapkan, baik penganggaran untuk pembangunan fisik maupun penganggaran untuk mengelola kehidupan sosial ekonomi pasar.

Ketersediaan sumberdaya lahan terlihat dari kepemilikan Pemkot Yogyakarta terhadap lahan seluas 15.605 meter persegi di Dongkelan yang memungkinkan dilaksanakannya pembangunan PASTY. Melalui kepemilikan lahan yang cukup memadai untuk menampung ratusan pedagang satwa dari Pasar Ngasem, pemerintah tidak perlu melakukan sewa atau melakukan pembelian lahan dalam rangka membangun PASTY.

Ketersediaan SDM yang memadai dapat dilihat dari kualitas dan kuantitas tenaga kerja yang digunakan dalam pembangunan fisik PASTY. DBGAD memiliki pegawai dengan latar belakang pendidikan tinggi bidang teknik arsitektur yang relevan memimpin proyek pembangunan PASTY. Secara teknis, DBGAD juga bekerjasama dengan pihak swasta yang telah memiliki standar kerja termasuk dalam hal kebutuhan tenaga kerja untuk perencanaan, pelaksanaan dan pemantauan proyek. Selain SDM dari pihak swasta, terdapat dukungan SDM dari kalangan akademisi yang bertugas melakukan analisis pemantauan proyek. Melalui ketersediaan SDM yang memadai tersebut, tercipta bangunan fisik PASTY yang sesuai dengan standar konstruksi dan memiliki umur ekonomis selama 25 tahun.

Ketersediaan SDM yang memadai juga terlihat dalam proses pembangunan kehidupan sosial ekonomi pasar. Secara khusus, Dinlopas menyediakan pegawai untuk bekerja di UPT PASTY dan hal ini tidak dilakukan pada pasar lain di wilayah Kota Yogyakarta. Selain itu, dukungan SDM pada pembangunan sosial ekonomi PASTY dapat dipahami dari kerjasama yang dibangun Dinlopas dalam mengelola kebersihan lingkungan pasar. Dinlopas menyerahkan pengelolaan kebersihan lingkungan PASTY kepada pihak swasta yang memiliki kualitas dan kuantitas tenaga kerja dengan standar tertentu.

Tabel 1 Anggaran dan realisasi anggaran pembangunan PASTY

\begin{tabular}{lcr}
\hline Uraian & $\begin{array}{l}\text { Anggaran } \\
\text { (dalam Rp) }\end{array}$ & \multicolumn{1}{l}{$\begin{array}{l}\text { Realisasi } \\
\text { (dalam Rp) }\end{array}$} \\
\hline Pembangunan & 5.500 .000 .000 & 5.087 .361 .000 \\
Fisik PASTY & 259.750 .250 & 235.065 .500 \\
$\begin{array}{l}\text { Optimalisasi } \\
\text { PASTY 2010 }\end{array}$ & 316.485 .250 & 309.572 .811 \\
$\begin{array}{l}\text { Optimalisasi } \\
\text { PASTY 2011 }\end{array}$ & 818.776 .138 & 769.228 .076 \\
$\begin{array}{l}\text { Optimalisasi } \\
\text { PASTY 2012 }\end{array}$ & 1.229 .241 .050 & 1.208 .909 .448 \\
$\begin{array}{l}\text { Optimalisasi } \\
\text { PASTY 2013 }\end{array}$ & 706.350 .000 & 670.385 .697 \\
$\begin{array}{l}\text { Optimalisasi } \\
\text { PASTY 2014 }\end{array}$ & & \\
\hline
\end{tabular}

Sumber: Diolah dari DBGAD dan Dinlopas Kota Yogyakarta

Selain berasal dari pemerintah, swasta dan akademisi, terdapat dukungan SDM yang berasal dari kalangan masyarakat. Hal tersebut dapat diamati dari keterlibatan paguyuban pedagang pasar dalam merespon dan mengelola berbagai permasalahan yang dihadapi secara kolektif. Keterlibatan masyarakat sekitar pasar dalam mengelola jasa parkir juga merupakan wujud nyata dukungan SDM yang berasal dari kalangan masyarakat dalam pembangunan PASTY. 
Berdasarkan paparan tersebut, dapat dipahami bahwa ketersediaan berbagai bentuk sumberdaya menjadi faktor penting yang mendukung tercapainya efektivitas dampak kesejahteraan pembangunan PASTY. Sumberdaya uang, sumberdaya lahan dan SDM merupakan bentuk-bentuk sumberdaya yang mendukung terwujudnya dampak kesejahteraan bagi masyarakat. Berdasarkan analisis pada kebijakan pembangunan PASTY, diperoleh sebuah pembelajaran penting bahwa dukungan sumberdaya dalam sebuah kebijakan tidak hanya berasal dari pemerintah namun juga bersumber dari pihak-pihak di luar pemerintah seperti masyarakat dan swasta.

\section{Kesimpulan}

Kebijakan investasi pembangunan PASTY yang diinisiasi oleh Pemkot Yogyakarta terbukti efektif memberikan dampak kesejahteraan. Hasil perhitungan Net Present Value menunjukkan nilai positif (+) sebesar $\mathrm{Rp}$ 25.946.473.622,00. Meskipun pemerintah terus mengalami kerugian dari aktivitas pembangunan PASTY, pedagang satwa, pedagang tanaman hias, pedagang makanan dan pengelola parkir mengalami dampak kesejahteraan karena nilai manfaat yang diperoleh lebih besar dibandingkan nilai biaya yang dikeluarkan.

Pedagang satwa mengalami tren penurunan kesejahteraan karena mereka cenderung memperkecil skala usaha ketika terjadi penurunan jumlah konsumen. Penurunan kesejahteraan tersebut juga terjadi karena terdapat pedagang liar di lingkungan pasar yang mengambil alih konsumen pedagang satwa. Kondisi ini tidak didukung dengan kemudahan akses pinjaman modal bagi pedagang satwa. Penurunan kesejahteraan tersebut harus menjadi perhatian pemerintah karena keberadaan pedagang satwa terbukti memberi dampak kesejahteraan bagi pedagang tanaman hias, pedagang makanan dan pengelola parkir.

Terdapat beberapa faktor yang mempengaruhi efektivitas kebijakan pembangunan PASTY yaitu dominasi elit pada proses formulasi kebijakan, kolaborasi berbagai pihak pada proses implementasi kebijakan, pembagian tugas dan tanggung jawab yang jelas pada organisasi pemerintah serta ketersediaan sumberdaya. Dominasi elit yang bersumber dari nilai budaya lokal pada proses formulasi kebijakan mampu menghasilkan mekanisme pengambilan keputusan yang cepat dan tanpa diwarnai konflik. Kolaborasi berbagai pihak dan pembagian tugas yang jelas pada proses implementasi kebijakan berhasil mewujudkan pembangunan komponen fisik serta kehidupan sosial ekonomi PASTY secara efektif. Ketersediaan sumberdaya berupa uang, lahan dan SDM yang berasal dari berbagai pihak juga memiliki peranan dalam mendukung pembangunan kehidupan sosial ekonomi pasar.

Berdasarkan analisis pada kebijakan investasi pembangunan PASTY, dapat dipahami bahwa investasi yang dilakukan daerah mampu membawa dampak kesejahteran bagi masyarakat. Meskipun efektif memberikan dampak kesejahteraan, tata kelola pemerintahan daerah yang baik melalui mekanisme kolaboratif berbagai pihak belum sepenuhnya terbentuk. Pemanfaatan nilai budaya lokal justru memunculkan dominasi elit pada proses kebijakan. Pembelajaran tersebut memunculkan sebuah tesis bahwa efektivitas dampak kesejahteraan dari sebuah kebijakan tidak sepenuhnya dihasilkan dari proses kebijakan yang kolaboratif.

\section{Daftar Pustaka}

Adelman, I. \& Cynthia Taft Morris. (1973). Economic Growth and Social Equity in Developing Countries. California: Stanford University Press.

Anderson, A., Paolo de Renzio \& Stephanie Levy. (2006). The Role of Public Investment in Poverty Reduction: Theories, Evidence and Methods. Working Paper 263. London: Overseas Development Institute.

Baker, A.M. \& Kimberly J. Sabo. (2004). Participatory Evaluation Essentials: A Guide for Non-Profit Organizations and Their Evaluation Partners. The Bruner Foundation, 2004.

Boardman, A. E., David H Greenberg, Aidan R Vining \& David L Weimer. (1996). Cost-Benefit Analysis: Concept And Practice. New Jersey: Prentice-Hall, Inc.

Bobrow, D.B \& John S. Dryzek. (1987). Policy Analysis by Design. Pittsburgh: University of Pittsburgh Press.

Boulding, K.E. (1958). Principles of Economic Policy. New Jersey: Prentice-Hall, Inc.

Dunia, Bank. (2001). Kualitas Pertumbuhan. Jakarta: PT Gramedia Pustaka Utama.

Dunn, W.N. (2000). Pengantar Analisis Kebijakan Publik. Yogyakarta: Gadjah Mada University Press.

Edward III, G.C. (1980). Implementing Public Policy. Washington, D.C.: Congressional Quarterly Press.

Halim, A ed.. (2008). Analisis Investasi Belanja Modal Sektor Publik-Pemerintah Daerah. Yogyakarta: STIM YKPN.

Hill, M. (2005). The Public Policy Process. Harlow: Pearson Education.

Hill, M. \& Peter Hupe. (2002). Implementing Public Policy. London: Sage Publications. 
Jones, C.P. (2004). Investments: Analysis and Management. New Jersey: John Wiley \& Sons, Inc.

Kim, P.S. (2011). Public Sector Reform in ASEAN Member Countries and Korea. Seoul: Daeyoung Moonhwasa Pulishing Company.

Mustafa, H. (2003). Modul Metode Penelitian. Bandung: Prodi Ilmu Administrasi Niaga, Fakultas Ilmu Sosial dan Ilmu Politik UNPAR.

Nugroho, R. (2008). Public Policy. Jakarta: Elex Media Komputindo.

Parsons, W. (2008). Public Policy: Pengantar Teori dan Praktik Analisis Kebijakan. Jakarta: Prenada Media Group.

Pearce, D., Giles Atkinson \& Susana Mourato. (2006). Cost-Benefit Analysis and the Environment: Recent Developments. Paris: OECD Publishing.

Purwanto, E.A. \& Sulistyastuti, D.R. (2012). Implementasi Kebijakan Publik. Yogyakarta: Gava Media.

Putra, F. (2003). Paradigma Kritis dalam Studi Kebijakan Publik. Yogyakarta: Pustaka Pelajar.

Samuelson, P.A. \& Nordhaus, W.D. (2001). Economics. New York: Mc Graw-Hill.

Stiglitz, J.E. (1988). Economics of The Public Sector. New York: W.W. Norton \& Company, Inc.

Subarsono. A. (2005). Analisis Kebijakan Publik. Yogyakarta: Pustaka Pelajar.

Turini, A. (2004). Public Investment and the EU Fiscal Framework. Economic Papers., Brussels: European Communities.

Weimer, D.L. \& Vining, A.R. (1998). Policy Analysis: Concept and Practice. New Jersey: Prentice-Hall, Inc.

Wibawa, S. (2011). Politik Perumusan Kebijakan Publik. Yogyakarta: Graha Ilmu.

Winarno, B. (2012). Kebijakan Publik: Teori, Proses dan Studi Kasus. Yogyakarta: Center for Academic Publishing Service. 